\title{
Characteristics of Wood and Charcoal from Eucalyptus clones
}

\author{
Macksuel Fernandes da Silva ${ }^{1}$, Myla Medeiros Fortes ${ }^{1}$, \\ Carlos Roberto Sette Junior ${ }^{1}$ \\ ${ }^{1}$ Universidade Federal de Goiás - UFG, Goiânia/GO, Brasil
}

\begin{abstract}
The characteristics of wood and charcoal depend on the genetic material and the sampling position on the tree trunk. The objective of this study was to evaluate the effect of clone and longitudinal position on the characteristics of wood and charcoal of Eucalyptus grandis $\mathrm{x}$ Eucalyptus urophylla. Specimens belonging to I144 and GG100 clones both at seven years of age were felled and mechanically processed for disc removal at different longitudinal positions of $0,3,6,9,12$ and 15 meters from the ground. The wood and charcoal physical and energetic characteristics were evaluated according to the different longitudinal positions. The genetic material and longitudinal position influenced the wood and charcoal characteristics. Sampling positions on the tree trunks can be considered for the energetic direction of "in natura" or carbonized biomass.
\end{abstract}

Keywords: bioenergy, longitudinal variation, GG100, I144. 


\section{INTRODUCTION}

Population growth and economic and technological acceleration have rapidly increased global energy demands. The widespread use of fossil fuels contributes to air pollution due to the release Greenhouse Gases (GHG) from their burning, considered one of the main agents responsible for climate change (IPCC, 2013; IEA, 2015).

In this regard, it is worth highlighting the need for global efforts to combat climate change: for example by increasing the proportion of renewable energy in the energy matrix, such as biomass. The use of forest biomass stands out given the representativeness of the Brazilian forestry sector and its potential for growth as being among the most sustainable in the world. Currently, planted forests represent an area of 7.8 million hectares, of which 5.6 million hectares consists of species from the Eucalyptus genus (IBÁ, 2016), with emphasis on Eucalyptus grandis $x$ Eucalyptus urophylla hybrids. Among the "urograndis" hybrids, we can highlight the clones I144 and GG100 due to their widespread cultivation due to their high productivitiy and suitable characteristics in the production of solid fuels, such as charcoal (Trugilho et al., 2001; Assis et al., 2012; Carneiro et al., 2014; Protásio et al., 2013; 2014).

Considered one of the most important inputs of the national steel/metallurgic industry, 4.6 million tons of charcoal were consumed in Brazil in 2015, of which $82 \%$ or 43 million cubic meters were produced from eucalyptus wood forest plantations (IBÁ, 2016). Charcoal represents an excellent raw material for the Brazilian steel industry due to its behavior as a fuel and reducer, its high purity, low production cost and for being a renewable and environmentally friendly product when produced from planted forests (Carneiro et al., 2017).

Charcoal quality depends on wood characteristics and the parameters used in the carbonization process (Trugilho et al., 1997; Nones et al., 2015; Castro et al., 2016). These characteristics vary depending on the genetic material and throughout the tree trunk. Therefore, the wood of a given clone and its longitudinal position may affect charcoal characteristics (Arantes et al., 2013; Buttini et al., 2013; Silva et al., 2015; Oliveira et al., 2017).

The effects of genetic material on wood and charcoal characteristics from eucalyptus have been observed by several authors such as Protásio et al. (2014) and Carneiro et al. (2017). The studies carried out by Trugilho et al. (2005), Arantes et al. (2013) and Buttini et al. (2013) with Eucalyptus species and clones indicate that the sampling performed on the tree trunks influences the quality of the charcoal produced. Despite these studies highlighting this, research relating the sampling position on the tree trunk and the biomass quality before and after carbonization is scarce. This evaluation may indicate and help guide which tree trunk parts have better characteristics for energy use of the biomass "in natura" or carbonized.

Therefore, the objective of this study was to evaluate the effect of clone and longitudinal position on the tree trunks of Eucalyptus grandis x Eucalyptus urophylla hybrids on the wood and charcoal characteristics.

\section{MATERIAL AND METHODS}

\subsection{Selection of trees, tree felling and sample preparation}

To evaluate the Eucalyptus wood and charcoal characteristics, ten 7-year-old trees from GG100 and I144 clones (Eucalytus grandis $x$ Eucalyptus urophylla clonal hybrids) were selected at random, with 5 trees of each clone from a forest plantation located in the city of Nerópolis in the central region of the State of Goiás (altitude of $832 \mathrm{~m}$ and geographic coordinates corresponding to $16^{\circ} 24^{\prime} 21^{\prime \prime} \mathrm{S}$ and $49^{\circ} 13^{\prime} 08^{\prime \prime} \mathrm{E} / \mathrm{W}$ ). The region is characterized by a tropical climate, classified as Aw according to Köppen and Geiger classifications, with average temperatures of $23.0^{\circ} \mathrm{C}$ and average annual rainfall of $1432 \mathrm{~mm}$.

The selected trees were felled and two wooden discs (each five centimeters thick) were cut at different longitudinal positions $0,3,6,9,12$ and 15 meters from the ground, as suggested by Sette et al. $(2013,2014)$. One of the disks from each tree and position was used to characterize the wood and the other to produce and characterize the charcoal.

For the wood characterization, the discs prepared from the different longitudinal positions were segmented into wedges and (i) two opposing wedges were used to determine wood basic density, while (ii) another two opposing wedges were transformed into sawdust using a Wiley mill and subjected to mechanical separation in an orbital shaker with intermittent beating sieves to 
select the retained fraction in an international No. 24 sieve with 60 mesh.

For charcoal production and characterization, the remaining discs collected from different longitudinal positions in the tree trunks were similarly cut into wedges, and pre-dried in an oven at $105^{\circ} \mathrm{C}$. The samples were carbonized in a muffle oven with dimensions of $60 \times 60 \times 70 \mathrm{~cm}$ equipped with a control system for temperature and time, using a heating rate of approximately $1.67^{\circ} \mathrm{C} . \mathrm{min}^{-1}$ and final temperature of $450{ }^{\circ} \mathrm{C}$, remaining stable at this temperature for 30 minutes (Assis et al., 2012; Arantes et al., 2013; Soares et al., 2014; Soares et al., 2015).

Gravimetric yield was determined after each carbonization; the charcoal was then milled using a Wiley mill and the samples were subjected to mechanical separation in an orbital shaker with intermittent beating sieves to select the retained fraction in an international No. 24 sieve with 60 mesh.

\subsection{Wood and charcoal characterization}

The analyses described below were performed on both wood and charcoal. The procedures for the proximate analysis are based on the ASTM E872-82 and ASTM D1102-84.34 standards (ASTM International, $2013 \mathrm{a}, \mathrm{c})$ to determine the volatile matter, ash and fixed carbon contents.

The high heating value (HHV) was determined according to the ASTM D5865-13 standard (ASTM International, 2013b) using an adiabatic calorimeter.

Wood basic density was determined according to the hydrostatic method by immersion in water, as described by the NBR 11941/2003 standard (ABNT, 2003) and the apparent relative density of charcoal was determined according to the method proposed by Vital (1984). The energy density was calculated from the product using the HHV value of the wood and the charcoal according to their respective densities.

\subsection{Statistical data analysis}

A completely randomized design was used for statistical data analysis arranged in a subdivided plot scheme, considering the trees as plots and the longitudinal positions as subplots. Analyses were carried out in the R program (R Core Team, 2017) using the ggplot2 package (Wickham, 2009) to acquire the graphs with regression adjustments. In this program, the "outliers", data normality and distributions, as well as an assumption of variance homogeneity were evaluated. After the assumptions were met, analysis of variance (ANOVA) was performed to verify the effect of the clone, the longitudinal position and the interaction between clone and position at 5\% probability.

\section{RESULTS}

\subsection{Wood and charcoal characteristics: effect of the clones}

The analysis of variance and the mean values for wood and charcoal characteristics from Eucalyptus grandis $x$ urophylla clones are presented in Tables 1 and 2, with the indication of a significant effect of the genetic material for some variables.

The wood basic density and the apparent relative density of charcoal were statistically higher in the GG100 clone than the I144 clone. The mean values obtained in this study for both wood (0.44-0.50 g. $\left.\mathrm{cm}^{-3}\right)$ and charcoal $\left(0.33-0.37 \mathrm{~g} . \mathrm{cm}^{-3}\right)$ are in agreement with those mentioned in the literature by Santos et al. (2011), Neves et al. (2011) and Carneiro et al. (2014).

The mean HHV values for wood and charcoal ranged from 4727-4733 kcal.kg-1 and 6830-6891 kcal.kg-1, respectively, with no significant effect from the clone being detected (Table 1). Neves et al. (2011), Carneiro et al. (2014) and Soares et al. (2015) reported that the high heating value for Eucalyptus sp. wood and charcoal are close to 4600 and $7000 \mathrm{kcal}^{\mathrm{kg}}{ }^{-1}$, respectively, corroborating the results found in the present study.

A significant effect of the clone was verified for the wood and charcoal energy densities, with higher values being observed for the GG100 clone (2.37 and $2.48 \mathrm{Gcal}^{-3} \mathrm{~m}^{-3}$, respectively) compared to the I144 clone (2.09 and 2.27 Gcal. $\mathrm{m}^{-3}$, respectively).

Analysis of variance of the proximate analysis parameters for the wood indicated a significant effect of the clones for ash content and not significant result for the volatile and fixed carbon contents, consistent with results found for different Eucalyptus sp. clones (Protásio et al., 2013; Arantes et al., 2013; Soares et al., 2014; Carneiro et al., 2017).

The proximate charcoal analysis indicated a significant effect of the clone for all levels, with higher values for 
Table 1. Analysis of variance and wood and charcoal characteristics from Eucalyptus clones.

\begin{tabular}{|c|c|c|c|c|c|c|c|}
\hline \multirow{3}{*}{ VF } & \multirow{3}{*}{ d.f. } & \multicolumn{3}{|c|}{ Charcoal } & \multicolumn{3}{|c|}{ Wood } \\
\hline & & ARD & HHV & ED & BD & HHV & ED \\
\hline & & $\left(\mathrm{g} \cdot \mathrm{cm}^{-3}\right)$ & $\left(\mathrm{kcal} . k g^{-1}\right)$ & $\left(\right.$ Gcal.m $\left.{ }^{-3}\right)$ & $\left(\mathrm{g} \mathrm{cm}^{-3}\right)$ & $\left(\mathrm{kcal} \mathrm{kg}^{-1}\right)$ & $\left(G_{c a l} \mathrm{~m}^{-3}\right)$ \\
\hline Clone & 1 & $0.008945^{\star}$ & 232 & $0.3546^{\star *}$ & $0.03349^{* * *}$ & 380 & $0.7316^{\star \star}$ \\
\hline Plot residue & 4 & 0.000432 & 105 & 0.0106 & 0.00032 & 11645 & 0.0145 \\
\hline GG100 & - & $0.37(6.8)$ & $6830(5.6)$ & $2.48(8.4)$ & $0.50(3.1)$ & $4727(3.3)$ & $2.37(4.7)$ \\
\hline I144 & - & $0.33(7.8)$ & $6891(7.2)$ & $2.27(12.8)$ & $0.44(3.8)$ & $4733(4.5)$ & $2.09(5.0)$ \\
\hline Position & 5 & $0.0017475^{\star}$ & $364477^{* * *}$ & $0.19596^{\star}$ & $0.0002335^{\star}$ & $51176^{* \star \star}$ & $0.028711^{* * *}$ \\
\hline Clone x Position & 5 & 0.0001506 & 29739 & 0.00833 & 0.00008517 & 12212 & 0.003994 \\
\hline $\begin{array}{c}\text { Sub-plot } \\
\text { residue }\end{array}$ & 20 & 0.0005534 & 82 & 0.05641 & 0.00004357 & 6187 & 0.002519 \\
\hline
\end{tabular}

${ }^{* * *} 0.001 ;{ }^{* *} 0.01 ;{ }^{*} 0.05 . \mathrm{VF}=$ variation factor; d.f.=degree of freedom; Mean followed by coefficient of variation. $\mathrm{ARD}=$ apparent relative density; $\mathrm{BD}=$ wood basic density; $\mathrm{HHV}=$ high heating value; $\mathrm{ED}=$ energy density.

Table 2. Analysis of variance and wood and charcoal characteristics from Eucalyptus clones.

\begin{tabular}{|c|c|c|c|c|c|c|c|c|}
\hline \multirow[b]{2}{*}{ VF } & \multirow[b]{2}{*}{ d.f. } & \multicolumn{3}{|c|}{ Charcoal } & \multirow[b]{2}{*}{ GY (\%) } & \multicolumn{3}{|c|}{ Wood } \\
\hline & & $\begin{array}{l}\text { Ash } \\
(\%)\end{array}$ & $\begin{array}{c}\text { Volatile } \\
(\%)\end{array}$ & $\begin{array}{c}\text { Carbon } \\
(\%)\end{array}$ & & $\begin{array}{l}\text { Ash } \\
(\%)\end{array}$ & $\begin{array}{c}\text { Volatile } \\
(\%)\end{array}$ & $\begin{array}{c}\text { Carbon } \\
(\%)\end{array}$ \\
\hline Clone & 1 & $1.655^{\star *}$ & $58.65^{\star *}$ & $79.89^{\star * *}$ & 7.385 & $0.06534^{*}$ & 0.0003 & 0.0742 \\
\hline Plot residue & 4 & 0.026 & 1.1 & 0.92 & 20.77 & 0.00797 & 0.4383 & 0.3956 \\
\hline GG100 & - & $\begin{array}{l}1.00 \\
(18.2)\end{array}$ & $\begin{array}{c}29.50 \\
(7.1)\end{array}$ & $\begin{array}{c}69.49 \\
(3.0)\end{array}$ & $30.99(14.0)$ & $\begin{array}{l}0.20 \\
(13.2)\end{array}$ & $\begin{array}{l}83.19 \\
(2.0)\end{array}$ & $\begin{array}{l}16.62 \\
(7.0)\end{array}$ \\
\hline I144 & - & $\begin{array}{l}0.62 \\
(15.3)\end{array}$ & $\begin{array}{c}26.95 \\
(9.6)\end{array}$ & $\begin{array}{c}72.43 \\
(6.0)\end{array}$ & $30.12(9.0)$ & $\begin{array}{c}0.13 \\
(8.9)\end{array}$ & $\begin{array}{c}83.18 \\
(1.0)\end{array}$ & $\begin{array}{l}16.69 \\
(5.0)\end{array}$ \\
\hline Position & 5 & $0.30894^{\star \star}$ & $36.68^{* * *}$ & $40.13^{\star * *}$ & 3.27 & $0.13723^{* * *}$ & $2.2661^{\star}$ & $3.1187^{\star *}$ \\
\hline Clone $\mathrm{x}$ Position & 5 & $0.14822^{*}$ & $31.66^{* * *}$ & $30.85^{\star * *}$ & 9.16 & $0.07697^{\star * *}$ & 1.5473 & 2.0302 \\
\hline Sub-plot residue & 20 & 0.04804 & 0.46 & 0.46 & 15.88 & 0.01108 & 0.8637 & 0.8627 \\
\hline
\end{tabular}

${ }_{* * *} 0.001 ;{ }^{*} 0.01 ;{ }^{*} 0.05 . \mathrm{VF}=$ variation factor; d.f. $=$ degree of freedom; GY= gravimetric yield. Mean followed by coefficient of variation.

fixed carbon (72.43\%) and lower values of ash (0.62\%) and volatile matter (26.95\%) in I144 clones compared to GG100 clones $(69.49 ; 1.00$ and $29.50 \%$, respectively).

Arantes et al. (2013) and Arruda et al. (2013) found similar mean values of fixed carbon (73 to $77 \%$ ) and volatile matter (18 to $24 \%$ ) in evaluating the charcoal from Eucalyptus grandis $x$ Eucalyptus urophylla clones under the same carbonization conditions (final temperature and heating rate). Santos et al. (2011) and Soares et al. (2014) found low levels of ash (0.33 to $1.53 \%$ ) evaluating different Eucalyptus sp clones and species.

The gravimetric yield of the charcoal had no significant difference between the clones, with 31\% for GG100 and 30\% for I144. Assis et al. (2012) found an average yield of $31.6 \%$ in evaluating the charcoal of Eucalyptus grandis x Eucalyptus urophylla clones under the same carbonization conditions as this study, corroborating the results observed.

\subsection{Wood and charcoal characteristics: the longitudinal position effect}

The analysis of variance (Tables 1 and 2) indicated a significant sampling position effect in the tree trunks for wood and charcoal characteristics, except for gravimetric yield. The clones' interaction with the longitudinal position was not significant for the variables of wood basic and apparent relative densities, high heating value and energy density, and the longitudinal position effect was similar between GG100 and I144 clones (Figure 1). A significant effect of the clone $\mathrm{x}$ longitudinal position interaction was observed for the variables of proximate analysis in the charcoal and for ash in the wood. 

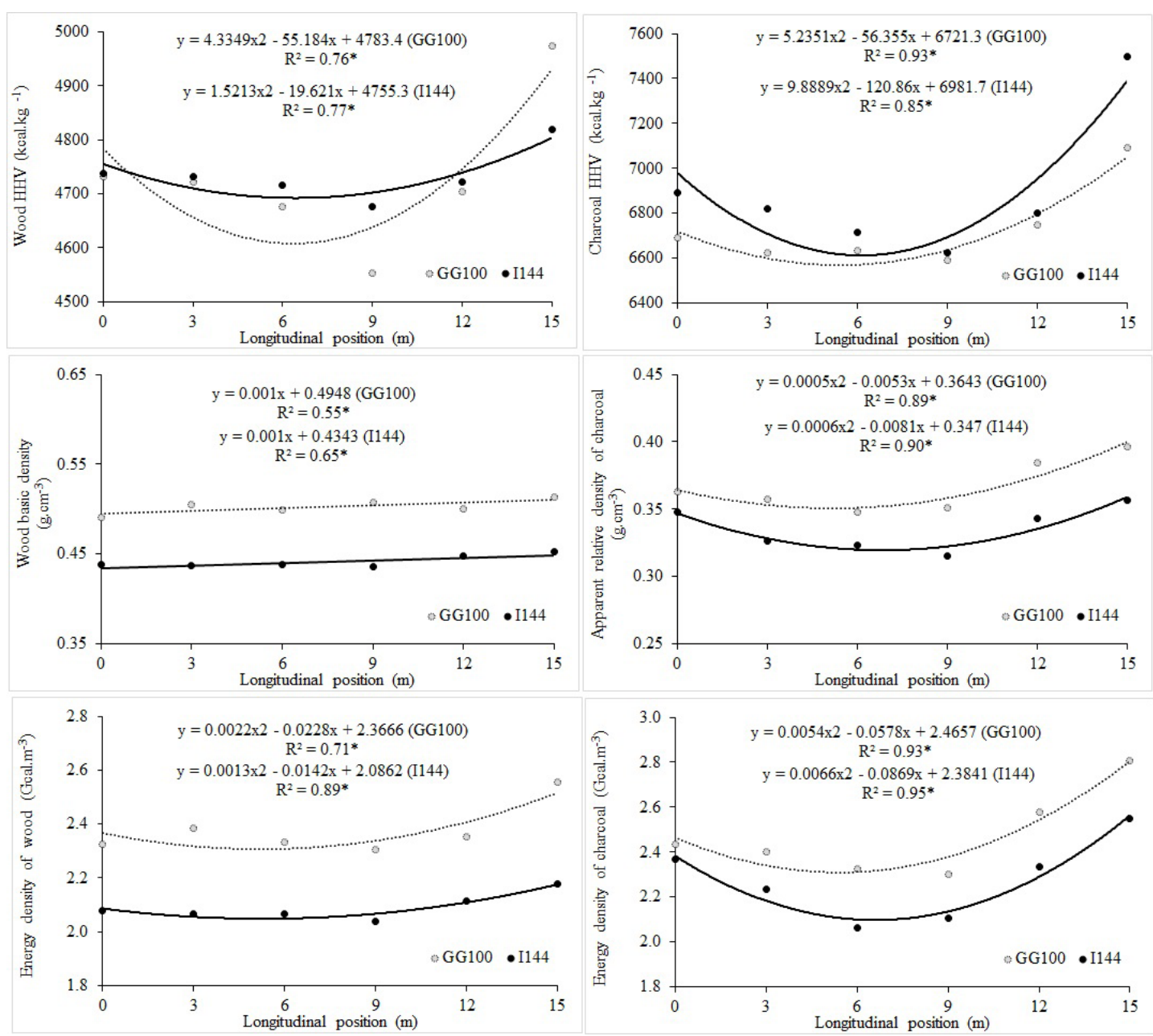

Figure 1. Longitudinal variation of high heating value (HHV), wood basic density, relative apparent density and energy density for the wood and charcoal of GG100 and I144 clones. ${ }^{*}$ significant at 5\% probability.

Regarding wood basic density and apparent relative density of charcoal, a linear increase was observed for both clones with smaller values at the base (0.49-0.44 g.cm ${ }^{-3}$ for wood; $0.36-0.35$ g.cm ${ }^{-3}$ for the charcoal), and higher values at the top of the trunk (0.51-0.45 g.cm gror wood; $0.40-0.36$ g.cm $^{-3}$ for the charcoal). Similar variations were observed in Eucalyptus sp. clones by Arruda et al. (2013) and Buttini et al. (2013).

A significant effect of the longitudinal position was observed in the wood and charcoal of the GG100 and I144 clones for HHV (Figure 1), with quadratic variation models for both clones presenting values of $4732-4737 \mathrm{kcal}^{-\mathrm{kg}^{-1}}$ at the base, followed by a reduction to $4552-4675 \mathrm{kcal}^{-\mathrm{kg}^{-1}}$ at the intermediate portion of the trunk, and an increase towards the top (4974-4819 kcal.kg-1). Similar trends were observed by Quinhones (2011) for Eucalyptus sp. wood clones.

A longitudinal position effect was detected for the energy density of the wood and the charcoal, with quadratic models for both clones and the two variables characterized by reduced values at the base (0-3 $\mathrm{m}$ height) up to the intermediate portion of the trunk ( $9 \mathrm{~m}$ height), followed by a gradual increase until the trunk top. This behavior is similar to that observed by Quinhones (2011) for the wood of Eucalyptus sp. clones at 7 years of age.

The gravimetric yield was not affected by the trunk sampling position in the Eucalyptus trees; therefore, regression models were not adjusted for the 
GG100 or I144 clones. In a study with Eucalyptus sp., Vieira et al. (2013) also found no differences between the gravimetric yields in charcoal in relation to different longitudinal positions.

The effect of longitudinal position was significant for the three proximate analysis variables (ash content, volatile matter content and fixed carbon content) for both wood and charcoal. Despite the significant effect, the data variation did not permit the adjustment of regression models, only being significant for ash content (GG100), and for volatile matter and fixed carbon contents (I144) in the charcoal (Figure 2).

A significant and strong effect of the interaction between the clones and the longitudinal positions was observed for these proximate analysis variables in both wood and charcoal. This interaction demonstrates that the longitudinal position affects the variables differently in the two clones studied. Arantes et al. (2013) also found differences in fixed carbon content and ash content in their study which evaluated four different longitudinal positions on trunks of Eucalyptus grandis $\mathrm{x}$ Eucalyptus urophylla.

\section{DISCUSSION}

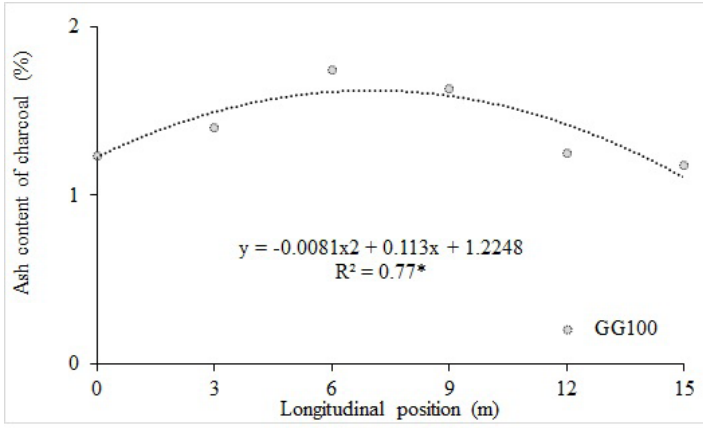

\subsection{Wood and charcoal characteristics: effect of the clones}

The higher wood basic density found in the GG100 clone is interesting and very important for selecting genetic material for energy applications. Wood density is directly related to optimizing the charcoal production in the carbonization furnaces. For the same volume, the denser the wood the greater the mass, and consequently the greater the charcoal production. High wood density values are also interesting for producing high density charcoals (Oliveira et al., 2010; Kumar et al., 2011), as also observed in this study for the charcoal density of the GG100 clone $\left(0.37 \mathrm{~g} . \mathrm{cm}^{3}\right)$ in comparison with the I144 clone $\left(0.33 \mathrm{~g} . \mathrm{cm}^{3}\right)$.

HHV was not influenced by the clone, and an increase of around $40 \%$ in the mean value of the wood (4727-4733 kcal. $\left.\mathrm{kg}^{-1}\right)$ and the charcoal were observed (6830-6891 kcal. kg $\left.{ }^{-1}\right)$. Soares et al. (2015) reported that the high heating value of charcoal is close to $7000 \mathrm{kcal}^{\mathrm{kg}}{ }^{-1}$, corroborating the results obtained in the present study. The increase of HHV in the charcoal in relation to "in natura" biomass is related to the carbonization process, where volatilization of oxygen

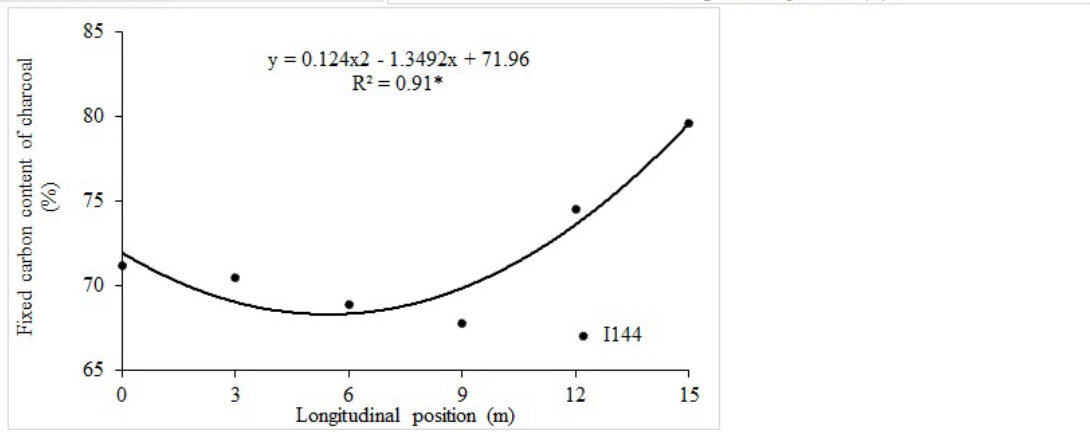

Figure 2. Longitudinal variation of ash content (GG100), volatile and fixed carbon contents (I144) of charcoal. * significant at $5 \%$ probability. 
and carbon concentration occur (Carneiro, 2013), as also observed in this study (Table 2).

Quantification and analysis of lignin content in the wood are fundamental characteristics for selecting Eucalyptus clones for bioenergy production due to the positive and linear relationship between this compound and the calorific value (Oliveira et al., 2017). Thus, in order to better explain the behavior of the GG100 and I144 clones, we recommend determining the lignin, holocellulose and extractive contents, as well as the $\mathrm{C}, \mathrm{H}$ and $\mathrm{O}$ concentrations, given that the energy characteristics are influenced by the chemical biomass composition.

Both for wood and charcoal, the energy density, which is the product between density and HHV, had trends similar to those observed for density, given that they are directly dependent on each other for their determination. The higher and more significant energetic densities observed for the wood and charcoal of GG100 in comparison to the I144 clone are the result of the higher densities of this clone, since the HHV did not vary greatly between the clones in either the wood or charcoal.

Energy density is an important parameter for solid fuels since it evaluates the amount of energy stored in a given volume of material. In the case of charcoal, the energy density values are higher than those of biomass resulting from increased HHV in the pyrolyzed material, despite the reduced density in the charcoals. A low energy density of the biomass in relation to petroleum and mineral coal implies higher transportation and storage costs (Couto et al., 2004), and in this sense pyrolysis is fundamental for increasing the use of biomass as an energy source.

Wood basic density and energetic density from the I144 clone were statistically lower than those of the GG100 clone, indicating the need for genetically improving this Eucalyptus clone for these properties when aiming for bioenergetic use of wood, as indicated by Protásio et al. (2014).

On the other hand, the charcoal produced with the wood from the I144 clone showed lower and significant levels of ash and volatile matter and higher levels of fixed carbon contents in relation to GG100 clones (Table 1).

High ash levels are related to the presence of different amounts and qualities of minerals present in biomass such as calcium, potassium, phosphorus, magnesium, iron, and sodium, among others (Vale et al., 2007). Higher levels of ash are not interesting from the energy perspective, since they contribute to reducing calorific value because they do not participate in the combustion process (Brand, 2010) and can cause damage to burner structures compromising iron quality, with consequent formation of cracks and fissures (Neves et al., 2011; Carneiro, 2013).

Fuels with high fixed carbon content are slower burning, implying more time inside burning appliances (Oliveira et al., 2010) which is one of the most important indicators of charcoal quality as a thermo reducer in the steel industry, contributing to the increase in blast furnace productivity (Carneiro, 2013).

The gravimetric yield of the charcoal showed no significant difference between the GG100 (31\%) and I144 (30\%) clones. According to Neves et al. (2011) when considering productive aspects, it is generally desirable to obtain high gravimetric yield in charcoal due to greater utilization of the wood in the carbonization furnaces, and consequently greater energy production.

As previously mentioned, in addition to the heating rate and final carbonization temperature, the gravimetric yield and the other energetic characteristics are influenced by the chemical biomass composition, with their determination being recommended to better explain the behavior of the clones.

\subsection{Wood and charcoal characteristics: effect of the longitudinal position}

Although the energetic application of wood from Eucalyptus trees typically included the entire trunk for direct burning or to produce charcoal, evaluating the longitudinal variation in the energy and physical characteristics of the biomass before and after carbonization can indicate and direct which parts of the tree trunk have better characteristics. Moreover, variations in wood quality along the trunk in the longitudinal and radial directions have been indicated in the literature by several authors (Protásio et al., 2014; Carneiro et al., 2017) as having a significant influence on charcoal quality, thereby making its investigation fundamental.

The findings of this study indicate that the longitudinal position along the trunk of Eucalyptus trees influences the energetic and physical characteristics of the wood and charcoal in the GG100 and I144 clones (Tables 1 and 2), 
except for the gravimetric yield. The effect of the positions was practically the same for both clones for wood basic density, apparent relative density of charcoal, high heating value and energy density.

The variation of wood basic density values followed a linear tendency of increasing from the base to the top of the trees for both studied clones. On the other hand, the apparent relative density of charcoal followed a positive quadratic trend, with maximum values also occurring at the trunk top. This tendency is observed in the literature for different Eucalyptus sp.: higher values of wood density in the apical region probably result from the mechanical support requirements of the tree canopy (Sette et al., 2012).

Mean HHV values for both wood and charcoal were also affected in a positive quadratic fashion by the position, with maximum values occurring at the trunk top for both clones (Figure 1). As indicated by Carneiro (2013), HHV is influenced by the chemical constitution of the wood, mainly regarding lignin and extractive contents, as well as carbon contents.

Although not determined in this study, the studies by Silva et al. (2005) and Sette et al. (2014) observed a growth tendency for these contents in the wood in relation to the position along the trunk of Eucalyptus sp. moving in the base-top direction. This fact may justify the significant effect of the longitudinal position observed in this study, with higher values at the base and at the top. Likewise, the increase of fixed carbon contents and reduced volatile and ash contents at the top of Eucalyptus trees, as observed for the GG100 and I144 clones (Figure 2), may explain the trend observed for HHV. The ratios found and indicated between HHV and fixed carbon contents, volatile materials and ash are usually indicated in the literature (Protásio et. al., 2011; Vale et al., 2001; Castro et al., 2016).

The energy density of wood and charcoal was also affected in a quadratic positive way by the longitudinal positions in both clones (GG100 and I144). As observed for the relative apparent density of charcoal and for $\mathrm{HHV}$, the energy density reached a maximum at the top of the trees and a minimum at the positions between 5 and $7 \mathrm{~m}$ of the trunk (from the ground). Thus, the effect of longitudinal position on energy density observed in this study is related to the significant effect observed for density and high heating value for both wood and charcoal (Figure 1).
In relation to proximate analysis (ash, fixed carbon and volatile materials), it was also possible to observe a strong interaction between the clone effects and the longitudinal positions, especially for charcoal. This is because volatile and carbon contents of the GG100 charcoal were much less affected by the longitudinal position than those from the I144 clone charcoal. Similar behavior was observed for the wood ash contents. These results indicate that the effect of position on the chemical variables of wood and charcoal may vary according to the genetic material. Therefore, their determination is recommended in clones used for energy purposes.

\section{CONCLUSION}

- The genetic material influenced the energetic and physical characteristics of the wood and charcoal.

- The energetic characteristics of the wood and charcoal were influenced by the longitudinal position on the tree trunk, except for gravimetric yield.

- The longitudinal position affected the GG100 and I144 clones in a similar way in terms of the wood basic density and apparent relative density of charcoal, high heating value and energy density.

\section{SUBMISSION STATUS}

Received: 26 june, 2017

Accepted: 29 sep., 2017

\section{CORRESPONDENCE TO}

\section{Carlos Roberto Sette Junior}

Departamento de Engenharia Florestal, Universidade Federal de Goiás - UFG, Rodovia Goiânia, Nova Veneza, CEP 74001-970, Goiânia, GO, Brasil e-mail: crsettejr@hotmail.com

\section{FINANCIAL SUPPORT}

Conselho Nacional de Desenvolvimento Científico e Tecnológico. 


\section{REFERENCES}

American Society for Testing Materials - ASTM International. ASTM D1102-84.34: standard test method for ash in wood. West Conshohocken; 2013a.

American Society for Testing Materials - ASTM International. ASTM D5865-13: standard test method for gross calorific value of coal and coke. West Conshohocken; 2013b.

American Society for Testing Materials - ASTM International. ASTM E872-82: standard test method for volatile matter in the analysis of particulate wood fuels. Phyladelphia; 2013c.

Arantes MDC, Trugilho PF, Silva JRM, Andrade CR. Características do carvão de um clone de Eucalyptus grandis W. Hill ex maiden x Eucalyptus urophylla S. t. Blake. Cerne 2013; 19(3): 423-431. http://dx.doi.org/10.1590/ S0104-77602013000300009.

Arruda TP, Hein PRG, Fonseca AS, Castro JP. Propriedades da madeira do híbrido Eucalyptus grandis x Eucalyptus urophylla para uso energético no Mato Grosso. Revista de Ciências Agroambientais 2013; 11(2): 127-136.

Assis MR, Protásio PT, Assis CO, Trugilho PF, Santana WMS. Qualidade e rendimento do carvão vegetal de um clone híbrido de Eucalyptus grandis $\mathrm{x}$ Eucalyptus urophylla. Pesquisa Florestal Brasileira 2012; 32(71): 291-302. http:// dx.doi.org/10.4336/2012.pfb.32.71.291.

Associação Brasileira de Normas Técnicas - ABNT. NBR 11941: densidade básica da madeira. São Paulo; 2003.

Brand MA. Energia de biomassa florestal. Rio de Janeiro: Interciência; 2010.

Buttini L, Capelari IP, Lima EA. Influência da posição do tronco nas características do carvão de Eucalyptus benthamii. Pesquisa Florestal Brasileira 2013; 327(1): 1-2.

Carneiro ACO. Pirólise lenta da madeira para produção de carvão vegetal. In: Santos F, Colodette J, Queiroz JH. Bioenergia e biorrefinaria: cana-de-açúcar e Espécies Florestais. Viçosa: UFV; 2013.

Carneiro ACO, Castro FNM, Castro RVO, Santos RC, Ferreira LP, Damasio RAP et al. Potencial energético da madeira de Eucalyptus sp. em função da idade e de diferentes materiais genéticos. Revista Árvore 2014; 38(2): 375-381. http://dx.doi.org/10.1590/S0100-67622014000200019.

Carneiro ACO, Vital B, Frederico P, Fialho L, Figueiró C, Da Silva C. Efeito do material genético e do sítio na qualidade do carvão vegetal de madeira de curta rotação. Floresta 2017; 46(4): 473-480. http://dx.doi.org/10.5380/ rf.v46i4.45704.

Castro AFNM, Castro RVO, Carneiro ACO, Santos RC, Carvalho AMML, Trugilho PF et al. Correlations between age, wood quality and charcoal quality of eucalyptus clones. Revista Árvore 2016; 40(3): 551-560. http://dx.doi. org/10.1590/0100-67622016000300019.
Couto L, Müller MD, Silva Júnior AG, Conde LJN. Produção de pellets de madeira: o caso da Bio-energy no Espírito Santo. Biomassa \& Energia 2004; 1(1): 45-52.

Indústria Brasileira de Árvore - IBÁ. Elatório Annual 2016. Brasília: IBÁ; 2016. 100 p.

Internacional Energy Agency - IEA. Energy and climate change: world energy outlook special report. Paris: IEA; 2015. 200 p.

Intergovernmental Panel on Climate Change - IPCC. Climate Change 2013: the physical science basis. Cambridge: Cambridge University Press; 2013. 1535 p.

Kumar R, Pandey KK, Chandrashekar N, Mohan S. Study of age and height wise variability on calorific value and other fuel properties of Eucalyptus hybrid, Acacia auriculaeformis and Casuarina equisetifolia. Biomass and Bioenergy 2011; 35(3): 1339-1344. http://dx.doi. org/10.1016/j.biombioe.2010.12.031.

Neves TA, Protásio TP, Couto AM, Trugilho PF, Silva VO, Vieira CMM. Avaliação de clones de Eucalyptus em diferentes locais visando à produção de carvão vegetal. Pesquisa Florestal Brasileira 2011; 31(68): 36-43.

Nones DL, Brand MA, Cunha AB, Carvalho AF, Weise SMK. Determinação das propriedades energéticas da madeira e do carvão vegetal produzido a partir de Eucalyptus benthamii. Revista Floresta 2015; 45(1): 57-64. http://dx.doi.org/10.5380/rf.v45i1.30157.

Oliveira AC, Carneiro ACO, Vital BR, Almeida W, Pereira BLC, Cardoso MT. Parâmetros de qualidade da madeira e do carvão vegetal de Eucalyptus pellita F. Muell. Scientia Forestalis 2010; 38(87): 431-439.

Oliveira AC, Pereira BLC, Salles TT, Carneiro ACO, Lana AQ. Análise de risco econômico de dois sistemas produtivos de carvão vegetal. Floresta e Ambiente 2017; 24(20): 245-265.

Protásio TP, Couto AM, Reis AA, Trugilho PF. Seleção de clones de Eucalyptus para a produção de carvão vegetal e bioenergia por meio de técnicas univariadas e multivariadas. Scientia Forestalis 2013; 41(97): 15-28.

Protásio TP, Goulart SL, Neves TA, Assis MR, Trugilho PF. Clones comerciais de Eucalyptus de diferentes idades para o uso bioenergético da madeira. Scientia Forestalis 2014; 42(101): 113-127.

Protásio TP, Trugilho PF, Neves TA, Vieira CMM. Análise de correlação canônica entre características da madeira e do carvão vegetal de Eucalyptus. Scientia Forestalis 2011; 40(95): 317-326.

Quinhones R. Relações entre as características da madeira e carvão de Eucalyptus sp. produzido a diferentes temperaturas finais de carbonização [tese]. Lavras: Universidade Federal de Lavras; 2011.

R Core Team. R: A language and environment for statistical computing [online]. Vienna: R Foundation for Statistical 
Computing; 2017. [cited 2017 Fev 02] Available from: https://www.R-project.org/

Santos RC, Carneiro ACO, Castro AFM, Castro RVO, Bianche JJ, Souza MM et al. Correlações entre os parâmetros de qualidade da madeira e do carvão vegetal de clones de eucalipto. Scientia Forestalis 2011; 39(90): 221-230.

Sette CR Jr, Oliveira IR, Tomazello M Fo, Yamaji FM, Laclau JP. Efeito da idade e posição de amostragem na densidade e características anatômicas da madeira de Eucalyptus grandi. Revista Árvore 2012; 36(6): 1183-1190. http://dx.doi.org/10.1590/S0100-67622012000600019.

Sette CR Jr, Tomazello M Fo, Silva FG Jr, Laclau JP. Alterações nas características químicas da madeira com a substituição do K por $\mathrm{Na}$ em plantações de Eucalipto. Revista Árvore 2014; 38(3): 569-578. http://dx.doi. org/10.1590/S0100-67622014000300020.

Sette CR, Laclau J-P, Tomazello M Fo, Moreira RM, Bouillet J-P, Ranger J et al. Source-driven remobilizations of nutrientes within stem wood in Eucalyptus grandis plantations. Trees (Berlin) 2013; 27(2): 827-839. http:// dx.doi.org/10.1007/s00468-012-0837-x.

Silva DA, Muller BV, Kuiaski EC, Eloy E, Behling A, Colaço CM. Propriedades da madeira de Eucalyptus benthamii para produção de energia. Pesquisa Florestal Brasileira 2015; 35(84): 481-485. http://dx.doi.org/10.4336/2015. pfb.35.84.677.

Silva JC, Matos JLM, Oliveira JTS, Evangelista WV. Influência da idade e da posição ao longo do tronco na composição química da madeira de Eucalyptus grandis Hill ex. Maiden. Revista Árvore 2005; 29(3): 455-460. http://dx.doi.org/10.1590/S0100-67622005000300013.

Soares VC, Bianchi ML, Trugilho PF, Höfler J, Pereira AJ. Análise das propriedades da madeira e do carvão vegetal de híbridos de eucalipto em três idades. Cerne 2015; 21(2): 191-197. http://dx.doi.org/10.1590/01047 760201521021294 .
Soares VC, Bianchi ML, Trugilho PF, Pereira AJ, Höfler J. Correlações entre as propriedades da madeira e do carvão vegetal de híbridos de eucalipto. Revista Árvore 2014; 38(3): 543-549. http://dx.doi.org/10.1590/S010067622014000300017

Trugilho PF, Lima JT, Mori FA, Lino AL. Avaliação de clones de Eucalyptus para produção de carvão vegetal. Cerne 2001; 7(2): 104-114.

Trugilho PF, Silva JRM, Lima JT, Mendes LM, Mendes LFB. Rendimentos e características do carvão vegetal em função da posição radial da amostragem em clones de Eucalyptus. Cerne 2005; 11(2): 178-186.

Trugilho PF, Vital BR, Regazzi AJ, Gomide JL. Aplicação da análise de correlação canônica na identificação de índices de qualidade da madeira de eucalipto para a produção de carvão vegetal. Revista Árvore 1997; 21(2): 259-267.

Vale AT, Costa AF, Gonçalez JC, Nogueira M. Relações entre a densidade básica da madeira, o rendimento e a qualidade do carvão vegetal de espécies do cerrado. Revista Árvore 2001; 25(1): 89-95.

Vale AT, Gentil LV, Gonçalez JC, Costa AF. Caracterização energética e rendimento da carbonização de resíduos de grãos de café (Coffea arabica L.) e de madeira (Cedrelinga catenaeformis), Duke. Cerne 2007; 1(3): 416-420.

Vieira RS, Lima JT, Monteiro TC, Selvatti TS, Baraúna EEP, Napoli A. Influência da temperatura no rendimento dos produtos da carbonização de Eucalyptus microcory. Cerne 2013; 19(1): 59-64. http://dx.doi.org/10.1590/ S0104-77602013000100008.

Vital BR. Métodos de determinação da densidade da madeira. Viçosa: Sociedade de Investigações Florestais; 1984.

Wickham H. ggplot2: Elegant graphics for data analysis. New York: Springer-Verlag; 2009. 